\title{
Tıp Akademisyenlerinin Kanıta Dayalı Bilgi Gereksinimleri ve Bilgi Arama Davranışları*
}

\author{
The Evidence Based Information Needs and Information \\ Seeking Behaviours of Medical Faculty
}

\author{
Eda KÖSE UYSAL ${ }^{* *}$ ve Nazan ÖZENÇ UÇAK***
}

\begin{abstract}
Öz
Günümüzde hekimlerin sadece deneyimlerine dayanarak hastalıkların tanı ve tedavisine yönelik karar vermeleri anlamını yitirmiş, kararların kanıtla desteklenmesi gereği ortaya çıkmıştır. Özellikle geleneksel tıp uygulamalarının yerini alan "Kanıta Dayalı Tıp" (KDT) uygulamaları, hastalıkların tanı ve tedavi süreçlerinde, doğru kararların verilebilmesi için sistemli bir yaklaşımla nitelikli ve güncel araştırmalarla desteklenmesini gerektirmiştir. Bu gelişmelere paralel olarak, tıp ve sağlık bilimlerinde çalışanların kanıta dayalı bilgiye yönelik gereksinimleri ve bilgi arama davranışları üzerine kullanıcı çalışmaları yoğunlaşmıştır.
\end{abstract}

Bu araştırmada tıp akademisyenlerinin kanıta dayalı bilgi gereksinimlerinin ve bilgi arama davranışı özelliklerinin ortaya konulması ve bu konuda unvanlar arasında benzerlikve farklılıkların belirlenmesi amaçlanmıştır.

Hacettepe Üniversitesi Tıp Fakültesinde görev yapan toplam 1053 akademisyen içerisinden seçilen 183 kişilik örneklem üzerine yürütülen bu çalışmada, yöntem olarak betimleme kullanılmış, veri toplama tekniği olarak ise anketten yararlanılmıştır.

Araştırma sonucunda tıp akademisyenlerinin kanıta dayalı bilgi gereksinimleri ve bilgi arama davranışları ile kaynak kullanımlarında unvanların etkisi ve KDT konusunda eğitime gereksinimleri olduğu saptanmıştır.

Anahtar sözcükler: Bilgi gereksinimi, Bilgi arama davranışı, Kanıta dayalı tıp, Tıp akademisyenleri

* Bu makale Hacettepe Üniversitesi Bilgi ve Belge Yönetimi Bölümünde hazırlanan “Tıp akademisyenlerinin kanıta dayalı bilgi gereksinimleri ve bilgi arama davranışları: Hacettepe Üniversitesi örneği” başlıklı yüksek lisans tezine dayanılarak hazırlanmıştır.

** Uzman kütüphaneci; Hacettepe Üniversitesi Sağlık Bilimleri Kütüphanesi, Sıhhıye, Ankara. (edakose@hacettepe.edu.tr)

*** Prof. Dr.; Hacettepe Üniversitesi Bilgi ve Belge Yönetimi Bölümü, Beytepe, Ankara. (ucak@hacettepe.edu.tr) 


\begin{abstract}
Today, it has become meaningless for physicians to decide diagnoses and therapeutics of diseases based only on experiences, it has elicited that the decisions should be backed up. Especially Evidence Based Medicine (EBM) practices replacing traditional medical practices require that diseases are supported with qualified and current researches in a systematic approach during the diagnosis and therapeutic processes in order to make correct decisions. Correspondingly, user studies on evidence based information needs and information seeking behaviours of the people working in medical sciences improve.

This research aims to present evidence based information needs and information seeking behaviour features of medical academics and to specify similarities and differences between titles.

In this research, carried out on a sample of 183 academics of 1053 academics working in Hacettepe University Faculty of Medicine, description method is used; questionnaire is used as data collection technique.

As a result of the research, it is seen that there are similarities and differences between titles in evidence based information need and information seeking behaviour features. It is also stated that usage of evidence based resources differ by titles and medical academics need to be trained on EBM.
\end{abstract}

Keywords: Information needs, Information seeking behaviour, Evidence based medicine, Medical faculty

\title{
Giriş
}

Binlerce yıllık tıp mesleği günümüzde hiç olmadığı kadar büyük bir değişim içindedir. Her gün yüzlerce bilimsel makalenin yayımlandığı ve internet aracılığı ile birkaç dakika içinde en son araştırmalar hakkında bilgi sahibi olunabildiği bir dünyada yaşanmaktadır (Sincan, 2003, s.64). Tıp alanındaki bilginin hızlı artışına paralel olarak tıbbi bilginin yayınlandığı bilgi kaynakları çeşitlilik göstermiş, özellikle internetin gelişimi ile birlikte tıbbi bilginin internet üzerinden zaman ve mekan sınırlaması olmadan erişimi sağlanmıştır. Tıp ve sağlık bilimlerindeki literatürün sürekli artması ve buna bağlı olarak teknolojik gelişimlerle bilginin yarı ömrünün 2-3 yıl gibi kısa bir süreye inmesi söz konusudur. Bilgi kaynaklarına ulaşımdaki gelişmeler ve yeni araştırma türlerinin ortaya çıkmasıyla son yıllarda tıp alanında Kanıta dayalı tıp (KDT) yaklaşımının ön plana çıktığı görülmektedir. KDT ile birlikte ortaya çıkan yaklaşım ve uygulamalar tüm sağlık alanını etkilemektedir.

Sağlık alanında yer alan farklı kullanıcı grupları içinde en acil bilgi gereksinimi olan grup tıp akademisyenleridir. Bu kullanıcılar araştırma, tanı, tedavi, prognoz', karar verme gibi çeşitli nedenlerle güncel ve kanıtlanmış bilgiye gereksinim duymaktadırlar. Günümüzde hekimlerin sadece deneyimlerine dayanarak hastalıkların tanı ve tedavisine

1 Prognoz: Bir hastalığın seyrini, olası gidişini ya da sonuçlarını önceden bilmek (Kaynak: Dökmeci, 2006, s.632). 
yönelik karar vermeleri anlamını yitirmiş, kararların kanıtla desteklenmesi gereği oluşmuştur. Özellikle geleneksel tıp uygulamalarının yerini alan KDT uygulamaları, hastalıkların tanı ve tedavi süreçlerinde, doğru kararların verilebilmesi için sistemli bir yaklaşımla nitelikli ve güncel araştırmalarla kararların desteklenmesini gerektirmektedir. Üretilen bilginin miktar ve hızındaki artış; bilgi kaynaklarının güvenilirlik, ulaşılabilirlik, kullanım kolaylığı, güncellik açısından farklı olması; araştırmaların analizine yönelik yeni çalışma türlerinin oluşması; araştırmaların kanıt değerlerini inceleyip değerlendirerek yeniden yayınlayan veri tabanlarının geliştirilmesi; başta sağlık bilimleri olmak üzere araştırmalarda maliyet, etkinlik, kalite kavramlarının giderek önem kazanması gibi nedenler KDT uygulamalarını gerekli ve önemli kılmıştır. Bu gelişmelerin kaçınılmaz bir sonucu olarak, kanıta dayalı bilgi tıp akademisyenleri tarafından önemli ve sık aranılan bilgi türleri arasında yerini almıştır. Son yıllarda tıp alanında çalışan kullanıcıların kanıta dayalı bilgi gereksinimleri ve kanıt kaynakları kullanım özellikleri üzerine yapılan araştırmaların arttığı görülmektedir. Tıp ve bilgi yönetimi literatüründe bu konuda farklı kapsam ve nitelikte çalışmaların sayısı artarken Türkiye'de konuyla ilgili araştırmaların yeterli olmadığı da bilinmektedir. Söz konusu çalışmaların sonuçları incelenmeden önce KDT ve kanıt bilgi kaynakları üzerinde durmakta yarar vardır.

\section{Kanıta Dayalı Tıp}

Klinik öğrenme yöntemini belirlemek ve geliştirmek amacıyla 1981 yılında Kanada'da McMaster Tıp Okulu'nda bir çalışma grubunun kurulmasıyla şekillenen KDT uygulamalarının 19. yüzyıl ortalarında Paris'te başladığı bilinmektedir. Ancak bu uygulamalar ilk kez 1991 yılında Guyatt (1991, s.A-16) tarafından "kanıta dayalı tıp" olarak adlandırılmıştır. Kanıta dayalı tıp uygulamaları önce Kanada ve Amerika Birleşik Devletleri (ABD) gibi Atlantik ötesi ülkelerde gelişmeye başlamış, daha sonra Avrupa'da, özellikle İngiltere'de yaygınlaşmıştır. KDT, geçmişi eskilere dayanmasına karşın, özellikle 1990'lı yılların başlarında önem kazanmaya başlayan bir alan olmuştur (Sackett, Rosenberg, Gray, Haynes ve Richardson, 1996; Sackett ve Richardson, 1997; Van Der Weyden, 1999). KDT'nin temelinin oluşturulması ve gelişiminde katkısı olan üç İngiliz bilim adamından biri olan Sir Ronald Fisher, 1900'lü yılların başlangıcında modern istatistiksel testlerin teorik temellerini geliştirmiştir. Ayrıca, Sir Austin Bradford Hill, 1937'de biyoistatistiksel yöntemlerin tıp araştırmalarında kullanımı konusunda yaptığı araştırma ve yayınlarla hastalığın tedavisinde kontrol gruplu rastgele deney uygulamalarının standart tedaviye göre daha üstün olduğunu göstermiştir. KDT'nin oluşumu ve gelişiminde büyük katkısı olan bir diğer araştırmacı Archie Cochrane'in ise sistematik derlemelerin (systematic reviews) gelişiminde çok önemli rolü olmuştur. Cochrane'in 1971'de basılan "Effectiveness and Efficiency" isimli kitabı klinik konularda KDT öğretimi ve uygulamaları konusundaki tartışmaları içermektedir. Cochrane ve grubu önce İngiltere sonra dünya çapında sistematik derlemeler için "Cochrane Kolaborasyonu" adında çok önemli bir çalışma geliştirmiştir (Sümbüloğlu ve Akdağ, 2010, s.11). 1993 yılında Cochrane Kolaborasyonu'nun kurulmasıyla tüm dünyada KDT 
uygulamaları büyük ölçüde netleşmiş ve yaygınlaşmıştır. Hekimlerin ve diğer sağlık personelinin tıp dergilerinde yayınlanan makalelere erişimleri, değerlendirmeleri ve kanıt olarak kullanabilmeleri için programlar oluşturulmuş ve konuyla ilgili eğitimler verilmeye başlanmıştır.

KDT, hastalıkların tanı ve tedavi sürecinde alınan kararlarda mevcut en iyi kanıtların dikkatli, şeffaf ve akılcı kullanımı olarak tanımlanmaktadır (Sackett ve diğerleri, 1996, s.72). Bir başka deyişle, KDT, eldeki en iyi kanıtın hekimin deneyimi ve hastanın tercihleri ile entegre edildiği sistematik bir yaklaşımı ifade etmektedir. Bu süreçte hekimler literatür incelemesiyle en iyi kanıtı bulur, değerlendirir ve kanıtı kendi bilgi ve becerisi, hastasının bireysel değerleri ve içinde bulunduğu koşulları birleştirerek uygular (Sümbüloğlu ve Akdağ, 2010, s.5-6). KDT'nin temel bileşenlerini hekimin deneyimi ve mesleki birikimi, sistematik literatür taramaları sonucu elde edilen en iyi kanıtlar, hastanın tercihleri ve içinde bulunduğu koşullar oluşturmaktadır (Babaoğlu, Yaşar, Dost ve Kayaalp, 2009, s.1299). KDT, bu üç unsurun bir arada değerlendirildiği bir süreçtir. Bu sürecin uygulanmasında belli amaçlarla bazı aşamaların uygulanması gerekmektedir.

KDT uygulamasının temel aşamalarının sayısı, çeşitli kaynaklarda farklılık gösterebilmektedir. Ancak genellikle KDT uygulamaları beş basamaklı bir süreçten meydana gelmektedir. Bunlar:

1. Bilgi gereksinimlerini yanıtlanabilir sorulara dönüştürmek

2. En iyi kanıtı bulmak için uygun kaynaklardan literatür taraması yapmak

3. Kanıtın geçerliliğini ve uygunluğunu değerlendirmek

4. Kanıt bilgileri uygulamaya geçirmek

5. Performansı değerlendirmek (Babaoğlu ve diğerleri, 2009, s.1300; Demirkan, Ekici, Uçar ve Başkan, 2000, s.222; Glasziou ve Del Mar, 2007, s.17; Hacettepe Üniversitesi Tıp Fakültesi Hekimlik Uygulamaları, 2004, s.21; McKibbon, 1998, s.396; Sackett, Straus, Richardson, Rosenberg ve Haynes, 2000, s.3-4).

\section{Kanıt Bilgi Kaynakları}

Günümüzde tıp ve sağlık bilimleri alanında bilimsel çalışmaların sayısı hızla artmaktadır. Belirli bir konuda yapılmış, birbirinden bağımsız çalışmalarda sıklıkla birbirinden farklı sonuçlara ulaşılmaktadır. Bu bilgi yığınını yorumlamak ve yeni araştırmalarda kullanabilmek için, kapsayıcı ve güvenilir nitelikte üst çalışmalara ihtiyaç vardır. KDT uygulamaları ile birlikte belirli bir konuda yapılan araştırmaların analizini sağlayan yeni kaynaklar gündeme gelmiştir.

Hekimler kararlarını mesleki deneyimlerine dayanarak verebilecekleri gibi bilimsel araştırmaların sonuçlarına dayanarak da vermektedirler. Geleneksel tıbbı uygulayan hekimler genellikle ders kitapları, kurumsal tanı ve tedavi rehberleri ve meslektaşlardan edinilen bilgilerden yararlanırken, KDT'yi uygulayan hekimler karar verebilmek için 
geniş tıp ve sağlık bilimleri literatürü içinden en güncel ve en iyi kanıtı kısa sürede veren kaynakları kullanmaktadırlar (Miles, Polychronis ve Grey, 2006, s.239).

Kanıt bilgi sunan kaynakların hepsi kanıt sunmalarına rağmen kanıt düzeyleri farklılık göstermektedir (Açıkel, 2009, s.164). Bu farklılık KDT uygulamalarının öneminin arttığı ve yaygınlaştığı 1990'lı yıllarda konuyla ilgili kurumları kanıtlar arasında bir hiyerarşi belirlemeye yöneltmiştir. Bilimsel araştırmaların kanıt düzeylerini belirleyen birçok ölçüt bulunmaktadır. Yaygın olarak kullanılan ve ülkemizde de T.C. Sağlık Bakanlığı'nın kendi tanı, tedavi rehberlerini geliştirirken esas almış olduğu "Scottish Intercollegiate Guidelines Network" (SIGN), Amerikan Koruyucu Hizmetler Komisyonu (US Preventive Services Task Force) ve İngiliz Ulusal Sağlık Kurumu (UK National Health Service) tarafından sınıflanan kanıt düzeyleri örnek olarak gösterilebilir (Açıkel, 2009, s.165; Babaoğlu ve diğerleri, 2009, s.1301).

KDT uygulamaları sürecinde bilinçli bir yaklaşım izleyerek kanıt bilgilere ulaşmak çok önemlidir. Kanıtlar, gerçek hastaların denek olarak kullanılmasıyla ve özgün, güçlü çalışma yöntemlerinin uygulanmasıyla gerçekleştirilen klinik araştırmaların bulguları arasından dikkatle seçilerek belirlenmektedir (Eldredge, 2000 aktaran: Alkan, 2005, s.46). KDT uygulamasının üç unsurundan biri olan, karar verme sürecinin destekleyicileri ve dayanakları olan bilimsel kanıtların nereden ve nasıl bulunabileceği ve kanıt bilgi sunan kaynakların neler olduğunun kanıt bilgi arayanlar tarafından bilinmesi gerekmektedir. Kanıta dayalı kaynaklar, farklı kaynaklarda değişik şekillerde gruplandırılmıştır. En yaygın olarak ise dört temel düzeyde incelenmektedir. Bunlar:

1. Özgün çalışmalar

2. Özgün çalışmaları sentezleyen kaynaklar

3. Özgün çalışmaları özetleyen kaynaklar

4. Özgün çalışmalara, bunların sentezlerine ve özlerine erişmeyi sağlayan sistemlerdir (Paisley, 2000, s.252 aktaran: Alkan, 2005, s.45).

Yukarıda belirtilen düzeyleri açıklamakta yarar vardır.

\section{1. Özgün Çalışmalar}

Özgün birincil kaynakların tümü kanıt bilgi sunmamaktadır. Kanıta dayalı bilgiler kliniklerde hastalar üzerinde yürütülen araştırma bulgularından elde edilmektedir (Alkan, 2005, s.46). Kanıt bilgi sunan özgün çalışmaları farklı gruplayan araştırmalar olmakla birlikte aşağıdaki gibi sıralamak mümkündür.

$\diamond$ Rastgele denetimli denemeler

$\diamond$ Kohort çalışmaları

$\diamond$ Olgu kontrol çalışmaları

$\diamond$ Tanısal testler 


\section{Rastgele Denetimli Denemeler}

Genel bir yaklaşımla rastgele denetimli denemeler, aynı hastalığa yakalanmış hastaların, araştırmacılar tarafından, tedavi ve kontrol gruplarına rastgele ayrılarak bulguların izlenip incelendiği deneylerdir (Goodman, 1993).

\section{Kohort Çalışmaları}

Özgün çalışmaların bir diğer türü olan kohort çalışmaları (cohort studies) ise bir hastalığın olası nedenlerinin araştırılması açısından güçlü ve değerli bir yöntem olup, birçok farklı parametrenin değerlendirmesine olanak tanıyan ve hastalığın doğal seyri konusunda en iyi kanıt bilgi veren çalışmalardır (Ergun, 2004, s.18). Kohort çalışmalarının büyük bir çoğunluğu etiyolojiye ${ }^{2}$ yöneliktir.

\section{Olgu Kontrol Çalışmaları}

Olgu kontrol çalışmaları (case control studies) belirli bir hastalığa sahip kişiler (olgular) ile bunlara benzer ancak hastalığı olmayan kişilerden (kontroller) oluşan grupları inceleyerek; olgular ile kontrol gruplarının etkene maruz kalma durumlarını karşılaştırmalı olarak değerlendiren çalışmalardır. Özellikle toplumda nadir görülen ve oluşma süresi uzun olan hastalıklarda bu araştırmaların kullanımı tercih edilmektedir (Çakır, t.y., s.147).

\section{Tanısal Testler}

Özgün çalışmaların bir başka türü olan tanısal testler (diagnostic tests) ise bir hastalığa tanı koymak üzere yapılan test ve tetkiklerin sonuçlarını değerlendirip bulgularını sunan kaynaklardır (Alkan, 2005, s.48).

\section{2. Özgün Çalışmaları Sentezleyen Kaynaklar}

Kanıt bilgi kaynaklarının ikinci düzeyini oluşturan özgün çalışmaları sentezleyen kaynaklar şunlardır:

$\diamond$ Sistematik derlemeler

$\diamond \quad$ Meta-analizler

$\diamond \quad$ Uygulama rehberleri

$\diamond$ Derleme makaleler

\section{Sistematik Derlemeler}

Sistematik derlemeler, araştırma süreci ve bulgularını raporlaştırarak veren çok sayıda birincil kaynağın bulgularını toplayan, çözümleyen ve bulguların sentezini sunan ikincil kaynaklardır. Bu derlemeler, kanıt bilgi sunan kaynaklar arasında kanıtı en üst

2 Etiyoloji: Hastalıkların nedenlerinin incelenmesi (Kaynak: Dökmeci, 2007, s.163). 
düzeyde veren kaynaklar olarak KDT uygulamalarının en önemli kaynaklarıdır. Belli bir sağlık sorununu ele alan bu kanıta dayalı kaynaklar, ilgili bütün birincil araştırma kaynaklarının toplanmasında bu kaynaklara eleştirel bir yaklaşımla değer biçilmesinde ve bulgularının sentezlenmesinde bilimsel yöntemler uygulanarak hazırlanırlar (Cook, Mulrow ve Haynes, 1997). Klinik uygulamalarda tanı, tedavi, etiyoloji ve prognoza yönelik kararların alınmasında en iyi kanıtları en üst derecede sağlayan kaynaklardır.

\section{Meta-analizler}

Meta-analiz (meta-analysis), belirli bir konuda yapılmış, birbirinden bağımsız, birden çok çalışmanın sonuçlarının birleştirilmesi ve elde edilen araştırma bulgularının istatistiksel analizinin yapılmasıdır. Meta-analizi, araştırmacılara çeşitli çalışmaların sonuçlarını özetleyen nicel veriler sunar ve sonuçların birleştirilmesi ile ortak yargıya ulaşmalarını sağlar (Akgöz, Ercan ve Kan, 2004, s.107). Meta-analizi, özellikle tedavi etkilerinin ve oluşabilecek risklerin hesaplanmasında güvenirlik ve kesinliği artırmak için kullanılmaktadır.

\section{Uygulama Rehberleri}

Uygulama rehberleri (practice guidelines), özellikle belirli klinik koşullarda kullanılmak, sağlığa ilişkin kararları desteklemek ve hekimlere danışmanlık sunmak üzere çeşitli konularda üretilen kaynaklardır. İçeriğindeki açıklamalar belirli bir düzen içinde verilmektedir (Alkan, 2005, s.51).

\section{Derleme Makaleler}

Derleme makaleler (review articles), belli bir alanda iki veya daha fazla yayının üzerinde inceleme yaparak sonuç ve değerlendirmeleri sentezleyen çalışmalardır. Belli bir konuyu geniş bir biçimde ele aldıkları için geniş kapsamlı soruları cevaplayabilirler. Bu nedenle kanıt sunmada diğer kaynaklara göre daha yetersizdirler.

KDT uygulamaları sürecinde genellikle meta-analizlerin, rastgele denetimli denemelerin ve sistematik derlemelerin kanıtlara ulaşmada daha çok kullanıldığı bilinmektedir.

\section{3. Özgün Çalışmaları Özetleyen Kaynaklar}

KDT uygulamalarının yaygınlaşmasıyla birlikte bu konuyla ilgili süreli yayınlar yayımlanmaya başlamıştır. Bunlar içinde en önemli olanları ve ilk yayımlanmaya başlayanları ise American College of Physicians (ACP) Journal Club ve Evidence Based Medicine'dır (Eldredge, 2000, s.289). ACP Journal Club ile Evidence Based Medicine birleştirilerek "Best Evidence" adıyla elektronik ortamda kullanıma sunulmaktadır (McKibbon, 1998, s.398). Daha sonraları ise Evidence Based Oncology, Evidence Based Ophthalmology, Evidence Based Mental Health gibi örneklerinin artırılabileceği, birçok alana özel kanıta dayalı dergiler yayımlanmaya başlamıştır. Kanıta dayalı süreli yayınlar, 
bir konu hakkında başka süreli yayınlarda çıkan klinik çalışmaların bulgularını içeren makaleleri seçimli olarak toplamakta ve makalelerdeki önemli gelişmelerin özlerini bir düzen içinde vermektedir.

\section{4. Özgün Çalışmalara, Bunların Sentezlerine ve Özlerine Erişimi Sağlayan Sistemler}

KDT uygulamalarının tıp ve sağlık bilimleri alanlarında yerini almasıyla birlikte bu konuya yönelik veri tabanları, kurum ve derneklerin web siteleri, açık erişim sistemler ve arama motorları oluşturulmuştur. Elektronik ortamda kanıt bilgileri içeren bu sistemler hızı ve kaliteli bir şekilde kanıtlara erişimi sağlayarak KDT uygulamaları sürecini kolaylaştırmaktadır. Kanıta dayalı bilgi sunan veri tabanlarından en önemlileri BMJ Best Practice, BMJ Clinical Evidence, The Cochrane Library, DynaMed, Essential Evidence Plus, Evidence Based Medicine Reviews, MD Consult, MEDLINE, PubMed, UpToDate'dir.

\section{Tıp Alanında Genel Bilgi Gereksinimi ve Bilgi Arama Davranışı}

Tıp akademisyenlerinin bilgi gereksinimleri ve bilgi arama davranışları üzerine yapılan araştırmalar 1950'li yıllara dayanmaktadır (Bates, 1996, s.155; Doğan, 2007, s.14; Herner, 1958, s.277). Bu dönemde yapılan çalışmalar daha çok tıp akademisyenleri, tıp alanında araştırmalar yapan bilim adamları, pratisyen ve uzman hekimler gibi kullanıcı gruplarının basılı kaynak ve kütüphane kullanımına yöneliktir. Bu grubun üyeleri hem araştırmacı, hem uygulamacı hem de eğitimci oldukları için bilgi gereksinimleri çok yönlüdür. Bu dönemde tıp kullanıcılarının en çok kullandıkları bilgi kaynaklarını belirlemek için çalışmalar yapılmıştır. Bu çalışmaların sonuçlarına göre ilk sırada dergiler olmak üzere indeks ve abstrakt gibi ikincil kaynakların çok kullanıldığı, bunun yanı sıra kitaplardan, meslektaşlardan ve konferanslardan elde edilen bilgilerin de bu grup için önemli olduğu tespit edilmiştir (Bowden, 1971, s.603; Bryant, 2000, s.85; DaRosa ve diğerleri, 1983, s.48; Dawes ve Sampson, 2003, s.11; Elayyan, 1988, s.250; Haug, 1997, s.223; Herner, 1958, s.281; Osiobe, 1985, s.971; Premsmit, 1990, s.385; Strasser, 1978, s.203-205; Thompson, 1997, s.189; Zawawi ve Majid, 2001, s.30-32).

\section{Tıp Akademisyenlerinin Kanıta Dayalı Bilgi Gereksinimleri ve Bilgi Arama Davranışları}

Tıpta kanıta dayalı uygulamalarla birlikte tıp ve sağlık bilimleri alanındaki kullanıcı gruplarının kanıt bilgiye yönelik bilgi gereksinimleri ve bilgi arama davranışları incelenmeye başlamıştır.

Hekimlerin kanıta dayalı bilgi kaynaklarını kullanmak yerine öncelikle meslektaşlarının konuyla ilgili görüşlerini almayı tercih ettikleri bilinmektedir. Ancak yapılan araştırmalar alınan görüşlerin tamamının kanıt değeri taşımadığını ortaya koymaktadır (McAlister, Graham, Karr ve Laupacis, 1999, s.236; Montori, Tabini ve Ebbert, 2002, s.114). Green ve Ruff (2005, s.176) hekimlerin klinik sorulara yönelik 
cevapları kanıt bilgi sunan kaynaklardan aramamaları nedeniyle sorunu yanıtlamada başarısız olduklarını saptamıştır. Kıdemli hekimlerin deneyimlerine dayanarak verdiği yanıt itibar edilir bir yanıt olmasına karşın doğruluğu test edilmemiş bir bilgi niteliği taşımaktadır (Sümbüloğlu ve Akdağ, 2010, s.9). Bu nedenle hekimlerin karar verme süreçlerinde literatürdeki kanıt bilgi sunan kaynakları kullanmaları önem taşımaktadır.

KDT uygulamalarında hekimler tarafından gereksinim duyulan bilgi türlerini 8 başlık altında toplamak mümkündür.

1. Tanısal bilgi,

2. Tedavi-prognoz bilgisi,

3. Etiyoloji bilgisi,

4. İlaç bilgisi,

5. Finansal bilgiler,

6. Testlerle ilgili bilgi,

7. Klinik bulgular ve uygulamalarla ilgili bilgi,

8. Risk faktörleri ile ilgili bilgi (Booth, 2000, s.212; Davies, 2007, s.82-83; Rosenberg ve Sackett, 1996, s.212; Sackett ve Rosenberg, 1995, s.620; Straus, Richardson, Glasziou ve Haynes, 2005, s.20; Wallace, 2007, s.93).

Tıp akademisyenleri sık sık yeni bilgilere gereksinim duymalarına rağmen bilgi aramak için yeterli zaman ayıramamaktadırlar. Bu nedenle sorularına yanıtlar ararken hızlı erişilebilen, kısa ve amaca yönelik özlü bilgiler içeren kaynakları tercih etmektedirler. (Chambliss ve Conley, 1996, s.143). Bu bağlamda hekimlerin karar verme süreçlerinde özetlenmiş, sentezlenmiş ve istatistiksel olarak güvenilirlikleri kanıtlanmış bilgileri içeren sistematik derlemeler, rastgele denetimli denemeler vd. gibi çalışma türlerini yararlı buldukları söylenebilir.

\section{Kanıta Dayalı Tıbbın Tıp Kütüphanelerine Etkisi}

Tıp literatüründeki artış ve sağlık alanında verilen kararların, yapılan uygulamaların kanıta dayandırılması gereği tıp kütüphanelerinin derme ve hizmet oluşumunu etkilemektedir. Yaşanan gelişmeler geleneksel tıp kütüphaneciliği anlayışının değişimine yol açmıştır.

Tıp ve sağlık bilimleri alanında kanıta dayalı uygulamaların yaygınlaşmasıyla bu alanda çalışanların kanıt bilgiye erişim ihtiyaçları artmış ve bu ihtiyaca yönelik hizmetlerin verilmesi için KDT kütüphaneciliği ortaya çıkmıştır. Son yıllarda Amerikan Tıp Kütüphaneleri Derneği (Medical Library Association-MLA) konunun önemine dikkat çekerek, tıp kütüphanecilerinin bilgiye erişim becerilerini kullanarak KDT sürecine katkıda bulunmalarının önemine değinmektedir (Eldredge, 2000, s.290). 
KDT kütüphaneciliği; klinik sorunun formüle edilmesi, sorunun cevaplandırılması için kanıt aranması, kanıt değeri taşıyan kaynakların bulunması, toplanan kanıtların kullanışlılığının ve geçerliliğinin sistematik olarak değerlendirilmesi süreçlerini içermektedir. KDT, kütüphanecilerin geleneksel işlevlerinin kapsamını genişletmiş ve literatür taraması yapmanın ötesinde farklı uygulama alanlarında çalışma gereği getirmiştir. Bu uygulama gelenekselden farklı olarak kütüphanecinin gelişmiş tarama olanaklarını kullanarak kanıt bilgi sunan literatüre en kısa zamanda, kanıt bilgi kaynaklarından, en isabetli bir şekilde erişmesini ve eriştiği literatürü güvenirlilik ve kanıt sunma düzeyi bakımından eleştirel bir şekilde değerlendirmesini, bilgiyi sentezlemesini ve bir rapor biçiminde hekime sunulmasını gerektirmektedir (Scherrer ve Dorsch, 1999, s.324). Kullanıcılarının bilgi gereksinimini karşılayabilmeleri için öncelikle tıp kütüphanecilerinin KDT uygulamaları ve KDT kütüphaneciliği hizmetlerinin farkında olmaları ve hizmetlerini kullanıcılarına bu doğrultuda sunmaları gerekmektedir. Tıp ve sağlık bilimleri alanındaki uygulama ve araştırmaların en güncel ve doğru bilimsel kanıtlara dayandırılmasını gerektiren KDT uygulamaları, tıp kütüphanecilerinin sürecin içinde yer aldığı bir ekip çalışmasıdır.

\section{Çalışmanın Amacı, Kapsamı ve Yöntemi}

Araştırmada tıp akademisyenlerinin KDT konusunda farkındalıkları, konuyla ilgili bilgi gereksinimleri ve bilgi arama davranışları; KDT konusunda en fazla tercih edilen bilgi kaynakları; bilgiye erişimde yaşanan sorunları ve hekimlerin KDT açısından kütüphaneyi nasıl değerlendirdikleri saptanmaya çalışılmıştır. Ayrıca bütün bu bulgulara unvanın etkisinin ne olduğunun araştırılması amaçlanmıştır.

Araştırma, Hacettepe Üniversitesi Tıp Fakültesi akademisyenleri üzerinde gerçekleştirilmiştir. Çalışmanın evreni toplam 1053 olup, örneklemi unvanlara göre "tabakalı rastgele örnekleme" ile belirlenmiştir. Örneklem genişliğinin tabakalara dağıtımı unvana göre orantılı dağıtım yöntemi ile yapılmış ve gereksinim duyulan örneklem genişliği 183 olarak bulunmuştur (Tablo I).

Tablo I. Unvanlara Göre Örneklem Sayıları

\begin{tabular}{lrr}
\hline Unvan & Evren sayısı & Örneklem sayısı \\
\hline Araştırma Görevlisi & 578 & 100 \\
Uzman ve Öğretim Görevlisi $^{3}$ & 48 & 9 \\
Yardımcı Doçent & 34 & 6 \\
Doçent & 103 & 18 \\
Profesör & $\mathbf{2 9 0}$ & 50 \\
\hline Toplam & $\mathbf{1 0 5 3}$ & $\mathbf{1 8 3}$ \\
\hline
\end{tabular}

3 Araştırma kapsamında uzman ve öğretim görevlileri bir arada değerlendirilmiştir. 
Araştırmada betimleme yöntemi kullanılmış, veri toplama tekniği olarak anketten yararlanılmıştır. Araştırma için hazırlanan anket soruları çoktan seçmeli olup, birden çok seçeneğin önem sırasına göre işaretlenebileceği kapalı uçlu sorulardan oluşmaktadır. Ayrıca bu sorulara ilaveten deneklerin konuyla ilgili görüş ve önerilerini alabilmek amacıyla açık uçlu bir soru da sorulmuştur. Araştırmada toplam 10 kişiye ön-test yapılmıştır. Elde edilen veriler PASW 18 programı ile değerlendirilmiştir. Betimsel istatistiklerin yanı sıra unvanlar arası farklılıkların araştırılması için sınıflama ölçüm düzeyindeki değişkenlerin yapısına uygun olarak Fisher kesin (exact) ki-kare testi uygulanmıştır.

\section{Bulgular ve Değerlendirme}

\section{Genel Özellikler}

Çalışılan alan ve çalışma süresinin bilgi gereksinimi ve bilgi arama davranışı üzerine etkisi bilinmektedir. Bu nedenle araştırma kapsamında yer alan tıp akademisyenlerine hangi alanlarda ve ne kadar süredir hekimlik yaptıklarını saptamak amacıyla sorular sorulmuştur. Elde edilen sonuçlara göre, akademisyenlerin \% 42,6'sı (78) 0-5 yıl, \%14,8'i (27) 6-10 yıl, \%42,6'sı (78) 11 yıl veya daha uzun süredir hekimlik yapmakta; \%10,4'ü (19) temel tıp bilimlerinde, \%61,2'si (112) dahili tıp bilimlerinde ve \%28,4'ü (52) cerrahi tıp bilimlerinde çalışmaktadır.

Bilgi arama davranışlarında bilgisayar ve internet kullanma becerileri etkili olduğu için araştırmamızda tıp akademisyenlerinin bilgisayar ve internet kullanım becerileri ve sıklıklarına da yer verilmiştir. Araştırmaya katılan akademisyenlerin \%69,9'u (128) bilgisayar ve internet kullanım becerilerini "yeterli", \%28,4'ü (52) "kısmen yeterli" ve \%1,6'sı (3) ise "yetersiz" olarak belirtmiştir. Bilgisayar ve internet kullanma sıklığının da bilgi arama davranışlarıyla ilişkili olabileceği düşünülerek tıp akademisyenlerine bilgisayar ve interneti kullanmak için ne kadar süre ayırdıkları sorulmuştur. Araştırmaya katılan akademisyenlerin bilgisayar ve internet kullanım sıklıklarına bakıldığında \%91,8'inin (168) “her gün", \%8,2'sinin (15) ise "haftada birkaç kez" kullandığı bilgisi elde edilmiştir.

\section{Bilgi Gereksinimleri ve Bilgi Arama Özellikleri}

Akademisyenlerin bilgi gereksinimlerini ve bilgi arama özelliklerini ölçmek amacıyla sunulan seçenekleri tercih önceliklerine göre sıralamaları istenmiştir. İlk iki tercihleri dikkate alındığında "araştırma yapmak" amacıyla bilgi aramayı en çok tercih edenler \%71'lik bir oranla araştırma görevlileri iken "alanımla ilgili güncel bilgileri takip etmek" seçeneğini en çok tercih eden grup ise \%76'lık bir oranla profesörlerdir. Ayrıca, "tanı koyma" ve "tedavi" amaçlı bilgi arama seçeneklerinin tıp akademisyenleri tarafından öncelikli olarak görülmemesi dikkat çekici bir bulgudur. 
Elde edilen sonuçlar, tıp akademisyenlerinin bilgi ararken en çok bilginin doğruluğuna $(\% 72,1)$ ve güncelliğine $(\% 54,6)$ dikkat ettiklerini, bu özelliklerin tüm gruplar için öncelikli olduğunu ve bunu üçüncü sırada bilginin erişilebilir olması özelliğinin izlediğini göstermektedir.

Genel olarak tıp akademisyenlerinin çoğunluğu (\%71) elektronik ortamdan bilgi kullanmayı tercih etmektedirler. Bilgi kullanımında tercih edilen ortam ile bilgisayar ve internet kullanım sıklığı ve bilgisayar ve internet kullanım becerileri arasında anlamlı bir ilişkinin olup olmadığına bakıldığında gerek bilgisayar ve internet kullanım sıklığı (c ${ }^{2}$ $=4,705 ; p<0,03)$ gerekse bilgisayar ve internet kullanım becerileri $\left(c^{2}=11,290 ; p<0,001\right)$ ile elektronik ortam kullanımı arasında anlamlı bir ilişki olduğu görülmektedir.

Araştırmada tıp akademisyenlerinin kaynak tercihleri de araştırılmış bu amaçla bilgi gereksinimlerini en iyi karşılayan bilgi kaynağı türleri seçenekler halinde verilmiş ve ilk üç tercihlerini önem sırasına göre işaretlemeleri istenmiştir. Araştırmacıların ilk iki tercihleri dikkate alındığında bilgi gereksinimlerini karşılamada en fazla dergileri $(\% 60,1)$, konuyla ilgili web sitelerini $(\% 60,1)$ ve kitapları $(\% 44,3)$ tercih ettikleri elde edilen verilerden anlaşılmaktadır.

\section{Kanıta Dayalı Bilgi Gereksinimleri ve Bilgi Arama Davranışları}

$\mathrm{Bu}$ çalışmanın asıl amacı, hekimlerin kanıta dayalı bilgi gereksinimi ve bilgi arama davranışlarını ve konuyla ilgili farkındalığı ortaya koyabilmektir. Bu nedenle tıp akademisyenlerinin kanıta dayalı tıp kaynakları hakkındaki görüşleri, ne tür kanıtlara ve kaynaklara gereksinim duydukları, bunlara erişimde tercih ettikleri yollar ve erişimde karşılaştıkları sorunlar çalışma kapsamında araştırılmıştır. Elde edilen bulgular şu şekilde gruplandırılabilir:

\section{Kanıta Dayalı Bilgi Sunan Kaynaklar Hakkında Görüşler ve Gereksinim Sıklığı}

Genel olarak bakıldığında akademisyenlerin çoğunluğunun ( $n=124, \% 67,8)$ kanıta dayalı bilgi sunan kaynakları çalışmaları açısından "yararlı" buldukları görülmektedir. Kanıta dayalı bilgiye duyulan gereksinimin sıklığına bakıldığında, hekimlerin çoğunluğunun $(\% 44,3)$ "haftada birkaç kez" kanıta dayalı bilgiye gereksinim duyduğu anlaşılmaktadır. Araştırma görevlileri (\%43), uzman ve öğretim görevlileri $(\% 66,7)$ ve profesörler $(\% 48)$ en fazla "haftada birkaç kez", yardımcı doçentler $(\% 50,3)$ "her gün" ve doçentler ise $(\% 44,4)$ "ayda birkaç kez" kanıta dayalı bilgiye gereksinim duymaktadırlar. "Gereksinim duymuyorum" seçeneğini işaretleyenlerin sayısı ise ikidir. Akademisyenlerin kanıta dayalı bilgiye duydukları gereksinimin sıklığı ile unvanlar arasında anlamlı bir ilişkinin olup olmadığını analiz etmek için yapılan Fisher kesin ki-kare testine (c ${ }^{2}=21,290$; $p=0,121$ ) göre anlamlı bir fark bulunmamıştır. 


\section{Kanıt Kaynaklara Gereksinim Duyulan Konular}

Çalışmada, akademisyenlerin hangi amaçlarla kanıt kaynaklara gereksinim duydukları araştırılmıştır. Araştırmaya katılan hekimlerin genelde "tedavi-prognoz bilgisi", "klinik bulgular ve uygulamalar" ve "tanısal bilgi" bulmak amacıyla kanıt kaynaklara gereksinim duydukları anlaşılmaktadır. Ancak kanıt veren kaynakları kullanmada akademisyenler arasında statüye bağlı olarak farklılıklar olduğu görülmektedir.

Tıp akademisyenlerinin öncelikli olarak hangi amaçlarla kanıt aradıklarını anlamak için ilk tercihleri dikkate alındığında, Şekil 1'de de görüldüğü gibi unvanlara göre önceliğin değiştiği görülmektedir. Araştırma görevlileri ilk tercih olarak en fazla (\%35) tanı koyma, uzman ve öğretim görevlileri $(\% 77,8)$ tedavi ve prognoz, yardımcı doçentler $(\% 83,3)$ etiyoloji, doçentler $(\% 94,4)$ risk faktörleri ve profesörler ise $(\% 64)$ klinik bulgular ve uygulamalara ulaşmak amacıyla kanıt bilgi aramaktadırlar.

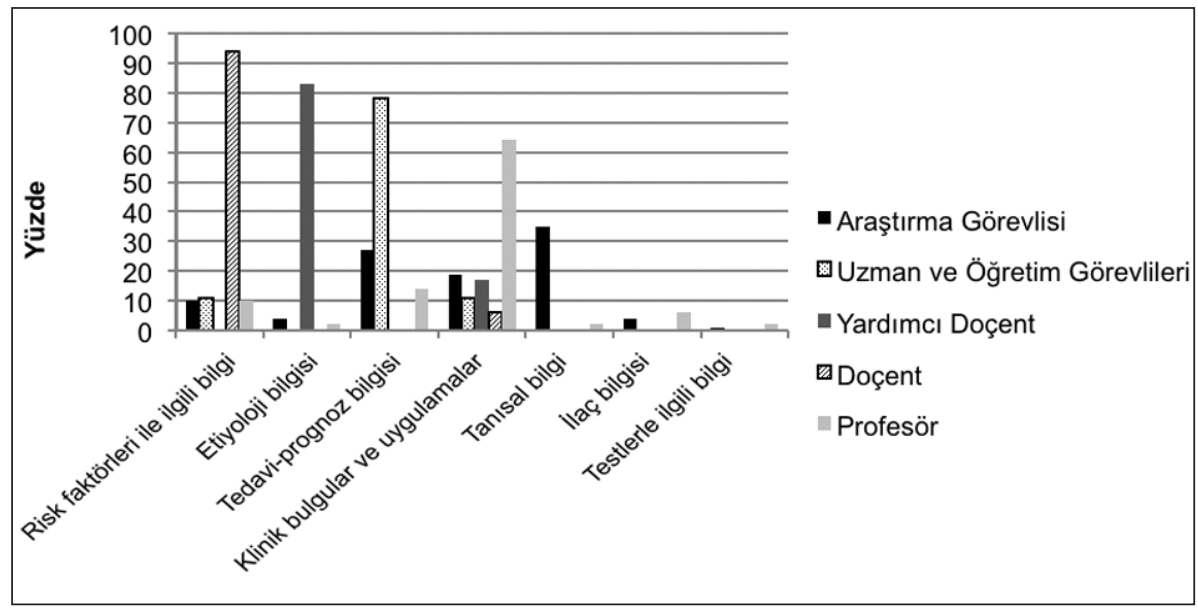

Şekil 1. Kanıt Kaynaklara Gereksinim Duyulan Konular

\section{Tercih Edilen Kanıta Dayalı Çalışma Türleri}

Genel olarak ankete katılanların ilk iki tercihleri dikkate alındığında kanıta dayalı çalışma türlerinden meta-analizleri ve derleme makaleleri eşit oranda $(\% 52,5)$ tercih ettikleri görülmektedir. Bunu \%44,8'lik oranla sistematik derlemeler izlemektedir.

Akademisyenlerin unvanlarını ve ilk tercihlerini dikkate aldığımızda, araştırma görevlilerinin kanıta dayalı çalışma türlerinden derleme makaleleri en fazla (\%77) işaretleyen grup olduğu görülmektedir. Diğer unvanlar arasında bu türü tercih edenlerin oranı düşük düzeydedir. Diğer akademisyenlere bakıldığında, uzman ve öğretim 
görevlileri $(\% 77,8)$, yardımcı doçent $(\% 50)$ ve doçentlerin $(\% 44,4)$ sistematik derlemeleri, profesörlerin (\%36) ise meta-analizleri ilk tercihlerinde belirttikleri görülmektedir (Şekil 2). Araştırmadan elde edilen bu bulgular doğrultusunda akademisyenlerin kanıta dayalı çalışma türlerindeki ilk tercihlerinde unvana göre farklılık olduğu söylenebilir.

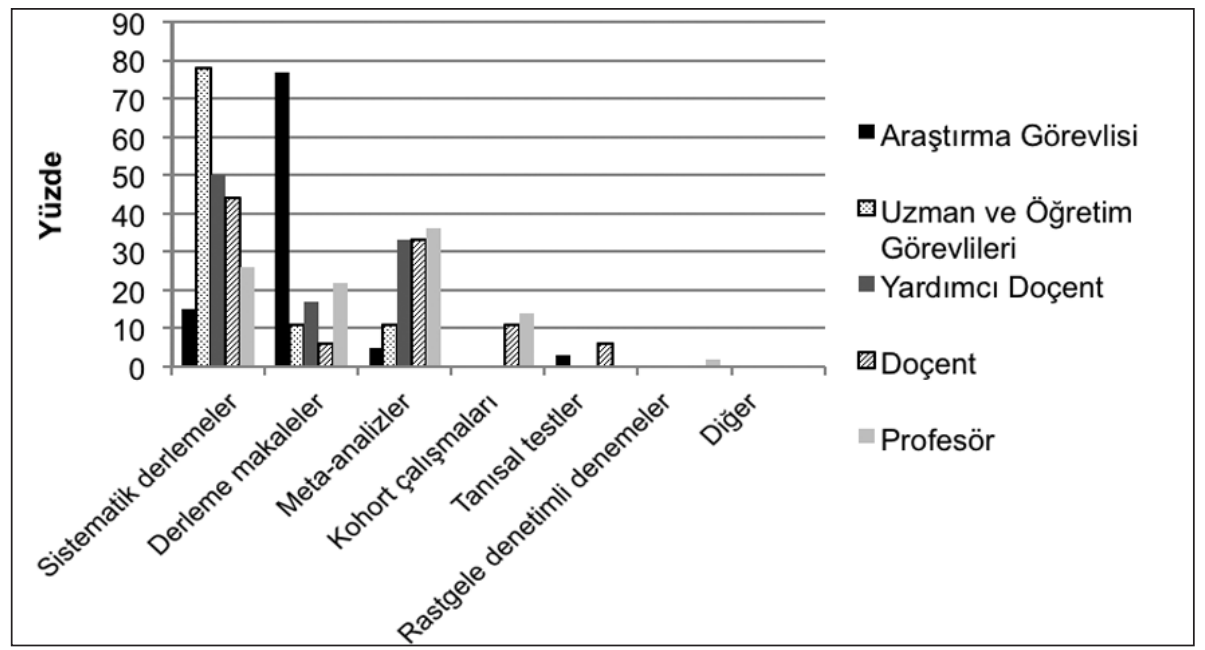

Şekil 2. Tercih Edilen Kanıta Dayalı Çalışma Türleri

\section{Kanıta Dayalı Bilgiye Erişimde Kullanılan Kaynaklar}

Tıp akademisyenlerinin kanıt veren bilgiye erişimde tercih ettikleri kaynaklar deneyimlerinden etkilenmekte, unvanlara göre farklılık gösterebilmektedir. Illk iki tercihlerin toplamı göz önüne alındığında akademisyenlerin $(\% 64,5)$ veri tabanlarını ağırlıklı olarak kullandıkları anlaşılmaktadır.

Tıp akademisyenlerinin kanıta dayalı bilgiye erişimde kullandıkları kaynaklara yönelik ilk tercihlerine ait veriler ise Şekil 3'te verilmiştir. Buna göre kanıta dayalı bilgiye erişimde araştırma görevlileri (\%41) en çok temel kitapları kullanmaktadırlar. Bu seçenek diğer akademisyenler tarafından çok az tercih edilmiştir. Diğer unvanlara bakıldığında ise uzman ve öğretim görevlilerinin $(\% 55,6)$ arama motorlarını, yardımcı doçentlerin $(\% 66,7)$, doçentlerin $(\% 72,2)$ ve profesörlerin (\%84) kanıta dayalı bilgiye erişimde veri tabanlarını tercih ettikleri görülmektedir.

Kanıta Dayalı Bilgi Tararken Tercih Edilen Yollar

Çalışmamızda, tıp akademisyenlerinin kanıta dayalı bilgi tararken aracı kullanıp kullanmadıkları, kütüphaneciden buamaçlayararlanıpyararlanmadıklarıtespitedilmeye çalışıımıştır. Seçenekler arasında "bu konuda tarama yapma gereği duymuyorum" seçeneği de sunulmuş, ancak bu seçeneği işaretleyen akademisyen olmamıştır. 


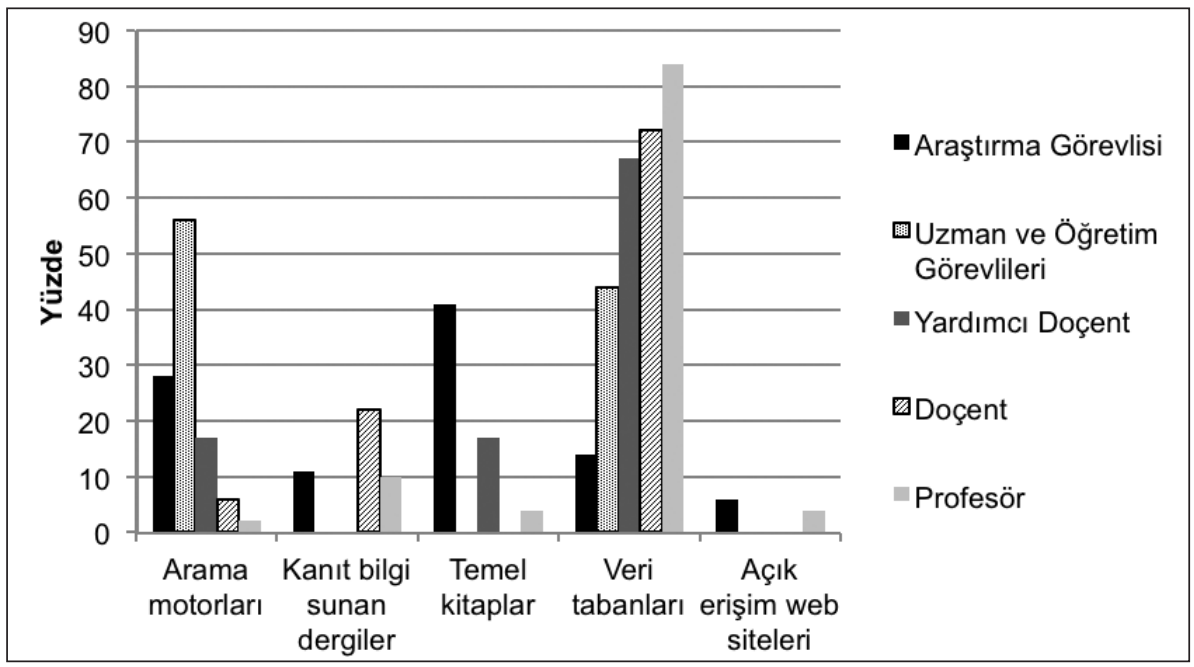

Şekil 3. Kanıta Dayalı Bilgiye Erişimde Kullanılan Kaynaklar

Ankete katılan tıp akademisyenlerinin büyük çoğunluğu $(\% 83,6)$ kanıta dayalı bilgi ararken yayın taramalarını kendileri yapma eğilimindedir. Yayın taramada unvanlar arasında aracı kullanma açısından fark olup olmadığına baktığımızda; uzman ve öğretim görevlileri ve yardımcı doçentlerin tamamının kendi taramalarını yaptıkları, başkasından yardım almadıkları anlaşılmaktadır. Bu oran araştırma görevlilerinde $\% 85$ iken profesörlerde \%82, doçentlerde ise \%66,7'dir. Araştırma görevlilerinin \%10'u, doçentlerin \%27'si ve profesörlerin \%12'si konuyu bilen bir araştırmacıdan yardım isterken, kütüphaneciden yardım istemenin en az tercih edilen seçenek olması dikkat çekicidir. Tüm akademisyenlerin sadece \%4,9’u (9) kanıta dayalı bilgi ararken kütüphaneciden yardım istemektedir. Bu durum bu konuda bireysel yeterliliğin yanı sıra kütüphaneciye duyulan güvenin zayıf olduğunu da ortaya koymaktadır. Yapılan Fisher kesin ki-kare testine $\left(c^{2}=5,973 ; p=0,552\right)$ göre kanıta dayalı bilgi taramada tercih edilen yol ile unvanlar arasında önemli bir fark yoktur.

Kanıta Dayalı Veri Tabanlarının Klinik-Kanıt Değeri ve Güncellik Açısından Değerlendirilmesi

Çalışmada tıp akademisyenlerinin kanıta dayalı veri tabanlarını klinik ve kanıt değeri açısından değerlendirmeleri de istenmiştir. Bu amaçla sorulan soruya ankete katılan akademisyenlerin \%55,7'si (102) "kısmen yeterli" ve \%42,1'i (77) "yeterli" yanıtını vermiştir. Bu sonuçlara göre genel olarak kanıta dayalı veri tabanlarının klinik ve kanıt değeri bakımından tıp akademisyenleri tarafından yeterli bulunduğu sonucuna varılmaktadır. 
Tıp alanında bilginin güncelliğinin önemi ve bilgi seçiminde oynadığı rol bilinmektedir. Akademisyenlerin kanıta dayalı veri tabanlarını güncellik açısından değerlendirmeleri istenmiştir. Elde edilen sonuçlara göre tıp akademisyenlerinin \%50,8'i (93) bu kaynakları güncellik açısından "yeterli" bulurken, \%46,4'ü (85) “kısmen yeterli" olarak değerlendirmiştir. Bu sonuçlara göre kanıta dayalı veri tabanlarının genel olarak güncel bulunduğu söylenebilir. Klinik-kanıt değeri ve güncellik açısından yapılan değerlendirmelerde akademisyenler arasında unvana göre önemli bir fark olmadığı görülmektedir.

\section{Kanıta Dayalı Bilgi Gereksinimini Karşılayan Veri Tabanları}

Tıp akademisyenlerine kanıta dayalı bilgi gereksinimlerini en iyi karşılayan veri tabanları sorulmuş, en çok tercih edilenler ve unvanlara göre veri tabanı seçiminde bir fark olup olmadığı araştırılmıştır. Elde edilen sonuçlar PubMed'in hekimler tarafından en fazla tercih edilen veri tabanı olduğunu göstermektedir. İlk iki tercih dikkate alındığında akademisyenlerin \%90,2'si kanıt bilgiye erişim için PubMed'i tercih etmektedir. İlk tercihler ve unvanlar dikkate alındığında da bu durum değişmemekte, PubMed tüm akademik unvanlar arasında en fazla tercih edilen veri tabanı olarak dikkat çekmektedir (Şekil 4).

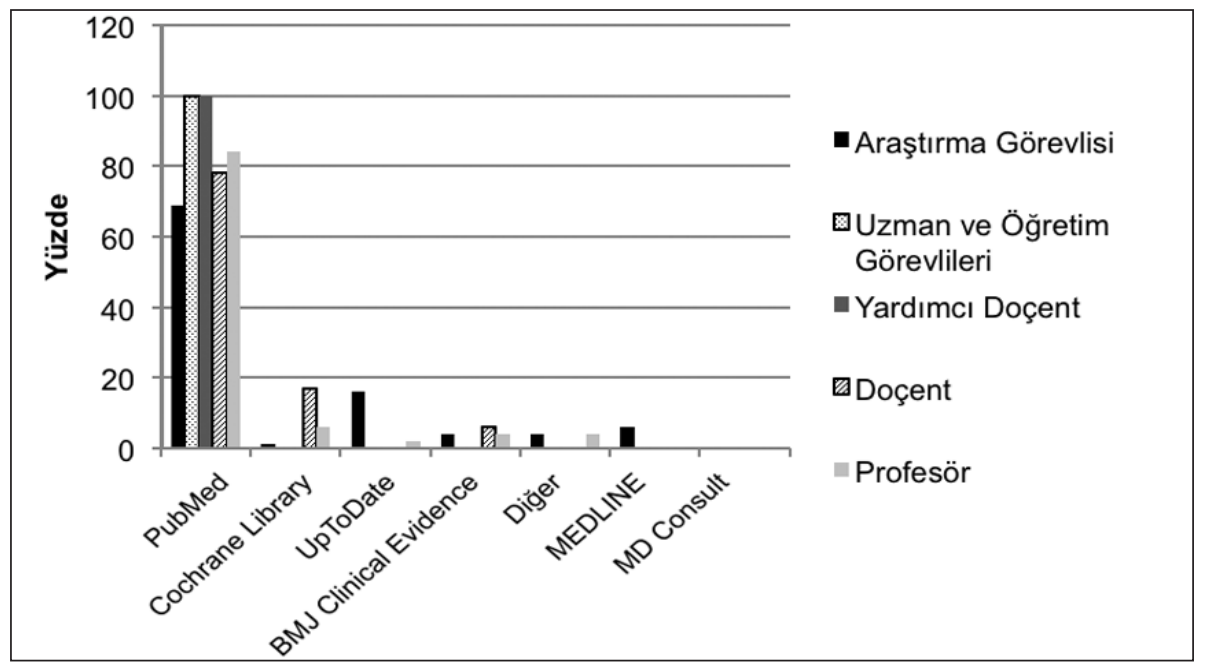

Şekil 4. Kanıta Dayalı Bilgi Gereksinimlerini Karşılayan Veri Tabanları

Akademisyenlerin ikinci tercihleri incelendiğinde kullandıkları veri tabanlarında farklılık olduğu anlaşılmaktadır. Araştırma görevlileri \%44'lük oranla MEDLINE'ı ikinci sırada en fazla tercih ederken; uzman ve öğretim görevlilerinin tamamı MD Consult'ı, yardımcı doçentlerin \%83,3'ü BMJ Clinical Evidence'ı, doçentlerin \%77,8'i UpToDate'i 
ve profesörlerin \%88'i CochraneLibrary'i ikinci sırada en fazla tercih edilen veri tabanı olarak işaretlemişlerdir.

Akademisyenlere seçenekler dışında kullandıkları veri tabanlarını belirtebilmeleri için "diğer" seçeneği sunulmuş ve kullandıkları veri tabanlarını yazmaları istenmiştir. Ankete katılanlar tarafından "diğer" seçeneğini işaretleyenler profesörler ve araştırma görevlileridir. Profesörler "Scopus", "Web of Science" ve "London Dysmorphology Database"i, araştırma görevlileri ise "Science Direct"i kanıt bilgiye erişimde kullandıkları veri tabanları olarak belirtmişlerdir.

\section{Kanıta Dayalı Bilgiye Erişimde Karşılaşılan Sorunlar}

Araştırmaya katılanlardan bilgiye erişimde karşılaştıkları sorunları önem sırasına göre birden üçe kadar işaretlemeleri istenmiştir. Ayrıca sorunlarla karşılaşmayanlar ve bu konuda bilgi ihtiyacı duymayanlara yönelik olarak "kanıta dayalı bilgiye erişme güçlüğü duymuyorum" ve "kanıta dayalı bilgiye erişme gereği duymuyorum" seçenekleri de sunulmuştur.

Ankete katılanlardan “kanıta dayalı bilgiye erişme güçlüğü duymuyorum” seçeneğini işaretleyenlerden 20'si profesör, 6'sı doçent ve 1'i araştırma görevlisidir. "Kanıta dayalı bilgiye erişme gereği duymuyorum" seçeneğini işaretleyen bir profesör vardır.

Araştırma için yeterince zaman bulamama $(\% 37,4)$ ve teknik sorunlarla karşılaşma $(\% 35,5)$ ilk iki tercihlerin toplamına göre tıp akademisyenlerinin kanıta dayalı bilgi erişiminde karşılaştıkları en önemli sorunlardır.

İlk tercihe göre kanıta dayalı bilgiye erişimde karşılaşılan sorunlar ve bunun unvanlara göre dağılımı ise şu şekildedir; araştırma görevlileri \%22,2 oranla "kanıt bilgi sunan kaynaklar hakkında yeterince bilgi sahibi olmama", uzman ve öğretim görevlileri $(\% 33,3)$ "teknik sorunla karşılaşma", yardımcı doçentler eşit oranda $(\% 33,3)$ "mevcut bilgiler içinden uygun olanı seçme zorluğu" ve "araştırma için yeterince zaman bulamama", doçentler eşit oranda (\%25) "kanıt bilgi sunan kaynaklar hakkında yeterince bilgi sahibi olmama" ve "teknik sorunla karşılaşma", profesörler ise (\%31) "bilgilerin güvenirliği ve geçerliliği konusunda şüphe duyma" sorunlarıyla karşılaşmaktadırlar.

\section{Kanıta Dayalı Tıbbi Bilgiye Erişim Konusunda Eğitim Gereksinimi}

Araştırma kapsamında hekimlerin kanıta dayalı bilgiye erişimde eğitime ihtiyaç duyup duymadıkları da araştırılmıştır. Tıp akademisyenlerinin \%60,7'si kanıta dayalı bilgiye erişim konusunda eğitime gereksinim duyduklarını, \%39,3'ü ise bu konuda eğitime gereksinim duymadıklarını belirtmişlerdir. Eğitime en fazla ihtiyaç duyan akademisyenler \%83,3'lük oranla yardımcı doçentlerdir. Bunu \%77'lik bir oranla araştırma görevlileri izlemektedir. Eğitime ihtiyaç duymadığını belirten akademisyenler ise sırasıyla \%66,7'lik oranla uzman ve öğretim görevlileri, \%64'lük oranla profesörler 
ve $\% 55,6$ 'ık oranla doçentlerdir. Kanıta dayalı tıbbi bilgiye erişim konusunda eğitime duyulan gereksinim ile unvanlar arasında anlamlı bir farkın olup olmadığını anlamak amacıyla yapılan Fisher kesin ki-kare testine göre ( $\left.c^{2}=299,889 ; p<0,000\right)$ aradaki farkın anlamlı olduğu anlaşılmaktadır.

\section{Kanıta Dayalı Tıp Veri Tabanlarının Öğrenilmesinde İlenen Yollar}

Özellikle kanıta dayalı tıp konusunda hazırlanan veri tabanlarının içeriği ve arayüz tasarımları farklı özellikler taşımaktadır. Bu veri tabanlarının içeriği ve kullanımı hakkında bilgi sahibi olmak kullanım oranlarını da artırmaktadır. Araştırma kapsamında akademisyenlere kanıta dayalı veri tabanlarını kullanmayı nasıl öğrendikleri de sorulmuştur. Tablo II'de ankete katılan akademisyenlerin çoğunluğunun (\%62) KDT veri tabanlarını kullanmayı bireysel çabalarıyla öğrendikleri görülmektedir.

Tıp akademisyenleri arasında genel olarak kütüphanede verilen eğitimle veri tabanlarını kullanmayı öğrenmenin düşük oranda (\%7) olması dikkat çekmektedir. Akademisyenlerin \%4'ü ise "diğer" seçeneğini işaretlemiştir. "Diğer" seçeneğini işaretleyenler katıldıkları kongrelerde, KDT konusunda verilen seminerlerde ve tıp eğitimleri sırasında gördükleri eğitim çalışmalarında bu kaynakları öğrendiklerini belirtmişlerdir. Bu bulgulardan, akademisyenlerin KDT veri tabanlarını kullanmayı izledikleri yollar arasında bireysel çaba ve meslektaşlardan öğrenmenin ağırlıklı olduğu anlaşılmaktadır.

Tablo II. Kanıta Dayalı Tıp Veri Tabanlarını Kullanmayı Öğrenme Yolları

\begin{tabular}{lccccccccccccc}
\hline & $\begin{array}{c}\text { Araştırma } \\
\text { Görevlisi }\end{array}$ & $\begin{array}{c}\text { Uzman ve } \\
\text { Öğretim } \\
\text { Üyeleri }\end{array}$ & $\begin{array}{c}\text { Yardımcı } \\
\text { Doçent }\end{array}$ & Doçent & Profesör & \multicolumn{2}{c}{ Toplam } \\
\hline & $\mathrm{n}$ & $\%$ & $\mathrm{n}$ & $\%$ & $\mathrm{n}$ & $\%$ & $\mathrm{n}$ & $\%$ & $\mathrm{n}$ & $\%$ & $\mathrm{n}$ & $\%$ \\
\hline $\begin{array}{l}\text { Bireysel çabalarımla } \\
\text { Meslektaşlarımdan }\end{array}$ & 51 & 51 & 8 & 89 & 3 & 50 & 16 & 89 & 36 & 72 & 114 & 62 \\
$\begin{array}{l}\text { Kütüphanede } \\
\text { verilen eğitimle }\end{array}$ & 49 & 1 & 11 & 1 & 17 & 1 & 6 & 7 & 14 & 49 & 27 \\
Diğer & 6 & 6 & 0 & 0 & 2 & 33 & 1 & 6 & 5 & 10 & 12 & 7 \\
\hline Toplam & $\mathbf{1 0 0}$ & $\mathbf{1 0 0}$ & $\mathbf{9}$ & $\mathbf{1 0 0}$ & $\mathbf{6}$ & $\mathbf{1 0 0}$ & $\mathbf{1 8}$ & $\mathbf{1 0 0}$ & $\mathbf{5 0}$ & $\mathbf{1 0 0}$ & $\mathbf{1 8 3}$ & $\mathbf{1 0 0}$ \\
\hline
\end{tabular}

\section{Kütüphane ile İlgili Değerlendirmeler}

Çalışmamızın bu bölümünde, tıp akademisyenlerinin KDT bilgi hizmetleri açısından Hacettepe Üniversitesi Tıp Kütüphanesi'ne yönelik değerlendirmelerine ilişkin bulgulara yer verilmiştir. 


\section{Kanıta Dayalı Tıp Veri Tabanları Hakkında Bilgilendirilme ve Eğitim Tercihleri}

Tıp kütüphanelerinin hizmetlerinden birisi de kullanıcılarına bilgiye erişimde gereken eğitimi vermektir. Eğitim programları düzenlenirken kullanıcı beklenti ve tercihlerinin de dikkate alınması gerekir. Araştırmamızda akademisyenlerin KDT veri tabanlarının tanıtımında hangi yolları tercih ettikleri sorulmuştur. Elde edilen sonuçlara göre tüm gruplar için "kütüphane web sayfasından kaynakların kullanımı hakkında bilgi edinmek" öncelikli olurken bunu "gereksinim anında birebir verilecek eğitim" seçeneği izlemektedir. En az tercih edilen eğitim şekli ise düzenli olarak yapılan tanıtıcı toplantılardır.

\section{Kanıta Dayalı Tıp Veri Tabanlarıyla Illgili Kütüphanenin Verdiği Eğitimin Değerlendirilmesi}

Kütüphanenin düzenlediği eğitim etkinliklerinden ne oranda yararlandıklarını ve bu eğitimleri nasıl değerlendirdiklerini saptamak amacıyla sorulan soruya verilen yanıtlar akademisyenlerin yapılan eğitim programlarından yeterince haberdar olmadıklarını göstermektedir. Tıp akademisyenlerinin çoğunluğu (\%54) kütüphane tarafından verilen KDT veri tabanı eğitimleriyle ilgili fikirleri olmadığını belirtmiştir. Genel olarak değerlendirilecek olursa, tıp akademisyenlerinin sadece $\% 5^{\prime i}$ bu eğitim programlarını "yeterli" bulurken, \%24'ü söz konusu eğitimleri "kısmen yeterli", \%17'si ise "yetersiz" bulmaktadır. Tablo III'te yer alan bu bulgular doğrultusunda akademisyenlerin büyük bir kısmının kütüphanenin konuyla ilgili verdiği eğitimler hakkında farkındalıklarının düşük olduğu söylenebilir.

Tablo III. Kanıta Dayalı Tıp Veri Tabanları Hakkında Kütüphanenin Verdiği Eğitimin Değerlendirilmesi

\begin{tabular}{lrrrrrrrrrrrrr}
\hline & $\begin{array}{c}\text { Araştırma } \\
\text { Görevlisi }\end{array}$ & \multicolumn{2}{c}{$\begin{array}{c}\text { Uzman ve } \\
\text { Öğretim Üyeleri }\end{array}$} & \multicolumn{2}{c}{$\begin{array}{c}\text { Yardımcı } \\
\text { Doçent }\end{array}$} & Doçent & Profesör & \multicolumn{2}{c}{ Toplam } \\
\hline \multicolumn{1}{r}{} & $\mathrm{n}$ & $\%$ & $\mathrm{n}$ & $\%$ & $\mathrm{n}$ & $\%$ & $\mathrm{n}$ & $\%$ & $\mathrm{n}$ & $\%$ & $\mathrm{n}$ & $\%$ \\
\hline Yeterli & 4 & 4 & 0 & 0 & 1 & 17 & 0 & 0 & 4 & 8 & 9 & 5 \\
Kısmen yeterli & 24 & 24 & 3 & 33 & 1 & 17 & 4 & 22 & 12 & 24 & 44 & 24 \\
Yetersiz & 23 & 23 & 1 & 11 & 2 & 33 & 1 & 6 & 5 & 10 & 32 & 17 \\
Fikrim yok & 49 & 49 & 5 & 56 & 2 & 33 & 13 & 72 & 29 & 58 & 98 & 54 \\
\hline Toplam & $\mathbf{1 0 0}$ & $\mathbf{1 0 0}$ & $\mathbf{9}$ & $\mathbf{1 0 0}$ & $\mathbf{6}$ & $\mathbf{1 0 0}$ & $\mathbf{1 8}$ & $\mathbf{1 0 0}$ & $\mathbf{5 0}$ & $\mathbf{1 0 0}$ & $\mathbf{1 8 3}$ & $\mathbf{1 0 0}$ \\
\hline
\end{tabular}

Kanıt Bilgi Sağlayan Basılı Kaynakların Değerlendirilmesi

Kullanıcıların kütüphane dermesinde yer alan kanıta dayalı bilgi gereksinimini karşılamaya yönelik basılı kaynaklar hakkındaki görüşleri de araştırılmıştır. Ankete katılanların büyük bir kısmının $(\% 58,5)$ kütüphane dermesindeki kanıt bilgi sunan kaynakları "yetersiz" buldukları söylenebilir. Kütüphanedeki kanıta dayalı bilgi sağlayan 
basılı kaynak dermesini yetersiz bulduğunu en fazla \%81'lik bir oranla araştırma görevlileri belirtmiştir. Konuyla ilgili kaynakları "yeterli" bulanlar ise sadece iki kişidir. Konuyla ilgili fikri olmadığını belirtenler içinde $\% 72,2$ 'lik bir oranla doçentlerin ve $\% 60$ 'ık bir oranla profesörlerin olması dikkat çekicidir. Elde edilen bu verilerden doçentlerin ve profesörlerin büyük bir kısmının kütüphanedeki kanıt bilgi sunan basılı kaynaklar hakkında farkındalıklarının düşük olduğu anlaşılmaktadır. Ayrıca tıp akademisyenlerinin kütüphane dermesinde kanıt bilgi sunan basılı kaynaklar hakkında değerlendirmelerinin ( $\left.c^{2}=69,449 ; p<0,000\right)$ unvanlara göre farklılık gösterdiği görülmektedir.

\section{Kanıt Bilgi Sağlayan Elektronik Kaynakların Değerlendirilmesi}

Basılı kaynaklar dışında konuyla ilgili kütüphanenin abone olduğu elektronik kaynakların hekimler tarafından nasıl değerlendirildiği araştırılmıştır. Ankete katılan akademisyenlerin \%32'si kütüphane dermesindeki kanıta dayalı bilgi sağlayan elektronik kaynakları "yeterli" bulurken,\%45,4'ü "kısmen yeterli" bulmaktadır. Kütüphanede bulunan elektronik kaynakları kanıt bilgi açısından en fazla "yeterli" bulanlar \%55,6'lık bir oranla doçentler; en fazla "kısmen" yeterli olarak değerlendirenler ise \%66,7oranıyla yardımcı doçentlerdir. Araştırma görevlilerinin \%15'i ve profesörlerin \%12'si ise konuyla ilgili elektronik kaynakların "yetersiz" olduğunu belirtmiştir. Yardımcı doçentlerin \%16,7'sinin ve araştırma görevlilerinin \%14'ünün kaynaklar hakkında fikirlerinin olmadığı anlaşılmaktadır. Elde edilen bu veriler kaynakların değerlendirilmesinde unvanlara göre anlamlı bir fark $\left(c^{2}=24,841 ; p<0,005\right)$ olduğunu ortaya koymaktadır.

\section{Kanıta Dayalı Tıp ile Illgili Görüşler ve Kütüphaneden Beklentiler}

Araştırmanın sonunda tıp akademisyenlerinden, KDT konusunda kütüphaneden beklentilerini ve konuyla ilgili belirtmek istedikleri görüşlerini yazmaları istenmiştir. Katılımcılardan alınan yanıtlara göre bazı hekimler kanıt bilgi sunan sistematik derlemeleri önemli bulduklarını ve araştırmalarında yoğun kullandıklarını belirtirken bunu tedavi maliyetini azaltmaya yönelik finansman bir yaklaşım olarak gören hekimler de olmuştur.

Kütüphane dermesi hakkında görüş bildiren akademisyenler çoğunlukla basılı kaynakların yetersizliği ve güncel olmaması üzerinde durmaktadır. Dermenin, tıp literatürünün kesiştiği alanlarla, özellikle istatistik, epidemiyoloji ve biyoloji konularında alınacak kaynaklarla desteklenmesi gereği vurgulanmaktadır. Bazı araştırmacılar elektronik kaynakların ve kütüphanenin abone olduğu veri tabanlarının çalışmalarındaki önemine değinmişlerdir.

Kütüphane hizmetlerine yönelik olarak belirtilen görüşler arasında kütüphanenin hastaneye uzak olmasının sakıncaları ve hastane içinde istekleri karşılayacak bir birimin olmasının önemi vurgulanmıştır. Ayrıca hekimler konuyla ilgili elektronik kaynaklara abone olmadan önce görüşlerinin alınmasını, tıp konusunun disiplinlerarası yapısı nedeniyle Beytepe Kütüphanesi'nde yer alan bazı kaynaklara erişimin kolaylaştırılmasını da istemektedirler. 
Görüşlerin belirtilmesi amacıyla sorulan açık uçlu soruya verilen yanıtlar arasında kütüphanenin eğitim hizmetleri ve personeli hakkında görüşler de yer almaktadır. Katılımcılar kütüphane eğitimine ağırlık verilmesini, yoğun çalışma saatleri nedeniyle kütüphanenin eğitim programlarına katılmada sorun yaşadıklarını, bu tür eğitimlerin kullanıcıların katılabileceği esnek programlarla veya web tabanlı düzenlenmesi gerektiğini belirtmişlerdir. Bazı katılımcılar personelin yardımcı olduğunu, bazı katılımcılar ise özellikle KDT konusunda kütüphanecinin daha bilgili olmasını beklediklerini ifade etmişlerdir.

\section{Sonuç ve Öneriler}

Tıp alanında KDT uygulamalarının yaygınlaşmasıyla, hekimlerin kanıta dayalı bilgi gereksinimleri artmış ve bilgi arama davranışları bu durumdan etkilenmiştir. Son yıllarda bu konuda yapılan araştırma sayıları artış göstermekle birlikte, ülkemizde tıp kullanıcıları üzerine yapılan çalışmaların yeterli olduğu söylenemez. Hacettepe Üniversitesi'nde çalışan tıp akademisyenleri üzerine yapılan bu çalışmada özellikle hekimlerin kanıta dayalı tıp konusunda farkındalıkları, bilgi gereksinimleri ve arama davranışları incelenmiştir. Araştırma sonucunda akademisyenlerin doğru ve güncel bilgiye gereksinim duydukları anlaşılmaktadır.

Akademisyenlerin bilgi arama amaçları ve kaynak tercihleri unvanlarına göre farklılık göstermektedir. Örneğin araştırma görevlileri en çok araştırma yapmak amacıyla bilgi arar ve kitapları tercih ederken, profesör ve doçentler en çok alanlarında güncel kalabilmek amacıyla bilgi aramakta ve dergileri kullanmayı tercih etmektedirler. Aynı şekilde bilgi ortamının seçiminde genelde hekimlerin büyük bir kısmı elektronik ortamı tercih etselerde, unvanlar arasında farklılık görülmekte, basılı ortamın en çok araştırma görevlileri tarafından kullanıldığı anlaşılmaktadır.

Araştırma sonucunda akademisyenlerin çalışmalarında yoğun olarak kanıta dayalı bilgiye gereksinim duydukları ve bu amaçla hazırlanan kaynakları yararlı buldukları görülmektedir. Gereksinim duyulan kanıta dayalı bilgi türleri de akademisyenlerin unvanlarına göre değişmektedir. Araştırma görevlileri en çok tanısal bilgiye ihtiyaç duyarken, uzman ve öğretim görevlileri tedavi-prognoz bilgisine; yardımcı doçentler etiyoloji bilgisine; doçentler risk faktörleri ile ilgili bilgiye ve profesörler ise klinik bulgular ve uygulamalarla ilgili bilgiye ihtiyaç duymaktadırlar.

Kanıt bilgi veren çalışma türleri de farklı unvanlar tarafından farklı önceliklerde değerlendirilmektedir. Araştırma görevlileri en çok derleme makaleleri kullanmayı tercih ederken, yardımcı doçentler ve doçentler sistematik derlemeleri, profesörler ise meta-analizlerini tercih etmektedirler. Bu bulgulardan, hekimlerin deneyimlerinin bilgi gereksinimleri üzerinde etkili olduğu ve kıdemleri arttıkça daha üst derecede kanıt bilgi sunan çalışma türlerini kullandıkları anlaşılmaktadır. 
Araştırma sonucunda akademisyenlerin kanıt bilgilere erişmek için veri tabanlarını yoğun kullandıkları anlaşılmaktadır. Kanıta dayalı veri tabanları klinik-kanıt değeri ve güncelliği açısından tıp akademisyenleri tarafından genelde yeterli bulunmaktadır. Bu veri tabanları içinde PubMed'in tüm hekimler tarafından öncelikli olarak tercih edildiği, bunun dışındaki veri tabanları kullanımında unvanlara göre farklılıkların olduğu saptanmıştır. Cochrane Library, BMJ Clinical Evidence ve UpToDate gibi kanıt verilere erişim konusunda uzmanlaşan veri tabanlarının daha çok doçent ve profesörler tarafından tercih edildiği görülmektedir. Ancak, tıp alanında kanıta dayalı bilgi sağlayan birçok önemli açık erişim web sitesi olmasına rağmen akademisyenler tarafından en az tercih edilen kaynak olması, bu konuda bilgi eksikliklerinin olduğunu ortaya koymaktadır.

Tıp akademisyenlerinin büyük çoğunluğu bilgi taramalarını kendileri yapmakta ve ilgili veri tabanlarının kullanımını kendi çabalarıyla veya meslektaşlarından öğrenmektedir. Bu konuda kütüphaneciden yardım almada isteksiz olmaları yeterliliklerini ortaya koymakla birlikte kütüphaneciye duyulan güvenin zayıf olduğunu da göstermektedir.

Kanıta dayalı tıbbi bilgiye erişim konusunda tıp akademisyenlerinin büyük bir çoğunluğunun eğitim gereksinimi vardır. Bu konuda eğitime duyulan gereksinim, akademik unvanlara göre farklılık göstermektedir. Bilgiye erişimde yaşanan sorunlara bakılınca kanıt kaynaklar ve kullanımları konusunda eğitim ihtiyacının olduğu anlaşılmaktadır. Hekimler arasında kıdem arttıkça bilgiye erişimde yaşanan sorunların ve eğitim ihtiyacının azaldığı söylenebilir.

Çalışmamızda elde edilen sonuçların tüm tıp kullanıcılarını temsil etmesi mümkün değildir. Bununla birlikte elde edilen bulguların, literatürdeki bulgularla benzerlik gösterdiği anlaşılmaktadır. Bu bulgular ışığında özellikle son yıllarda hızla gelişen KDT ve bu konudaki bilgi davranışlarını araştıran çalışmalara önem verilmesi, elde edilen sonuçların tıp kütüphanelerinin derme ve hizmet tasarımında kullanılarak bu kütüphanelerin kullanıcı beklentilerini daha iyi karşılamalarının sağlanması önerilebilir.

Ayrıca, KDT konusunda kütüphanecilerin üstlenmesi gereken roller hakkında farkındalığın yaratılmasının, gerekli insan gücünün yetiştirilmesi için lisans ve yüksek lisans eğitim programlarının yanı sıra hizmet içi eğitimlerle konuya ağırlık verilmesinin gereğini vurgulamakta yarar vardır. 


\section{Kaynakça}

Açıkel, C. (2009). Meta-analiz ve kanıta dayalı tıptaki yeri. Klinik Psikofarmakoloji Bülteni, 19(2), 164172.

Akgöz, S., Ercan, İ. ve Kan, İ. (2004). Meta-analizi. Uludağ Üniversitesi Tıp Fakültesi Dergisi, 30(2), 107112.

Alkan, N. (2005). Dizgesel derlemelerin kanıta dayalı tıp uygulamasındaki önemi ve dizgesel derleme üretme sürecinde kütüphanecilerin rolü. M.E. Küçük (Yay. Haz.). Prof. Dr. Nilüfer Tuncer'e Armağan içinde (ss.42-71). Ankara: Türk Kütüphaneciler Derneği.

Babaoğlu, M. Ö., Yaşar, Ü., Dost, T. ve Kayaalp, S. O. (2009). Kanıta dayalı tıp: Kavramlar, örnekler ve görüşler. Türkiye Klinikleri Journal of Medical Sciences, 29(5), 1298-1305.

Bates, M. J. (1996). Learning about the information seeking of interdisciplinary scholars and students. Library Trends, 45(2), 155-164.

Booth, A. (2000). Selecting appropriate sources. A. Booth ve G. Walton (Ed.). Managing knowledge in health services içinde (s.207-221). London: Library Association Publishing.

Bowden, C. (1971). A survey of information sources used by psychiatrists. Bulletin of the Medical Library Association, 59, 603-608.

Bryant, S. L. (2000). The information needs and information seeking behaviour of family doctors: A selective literature review. Health Libraries Review, 17, 83-90.

Chambliss, M. L. ve Conley, J. (1996). Answering clinical questions. The Journal of Family Practice, 43, 140-144.

Cook, D. J. , Mulrow, C. D. ve Haynes, R. B. (1997). Systematic reviews: Synthesis of best evidence for clinical decisions. Annals of Internal Medicine, 126(5), 376-380.

Çakır, B. (t.y.). Tıbbi araştırma teknikleri: Temel özellikler, yarar ve kısıtılılar, olası hata kaynakları. 12 Kasım 2010 tarihinde http://www.tfd-kfcg.org/newsletter/200903/tfd_kfcg_200903.html adresinden erişildi.

DaRosa, D. A., Mast, T. A., Dawson-Saunders, B., Mazur, J., Ramsey, D. E. ve Folse, J. R. (1983). A study of the information-seeking skills of medical students and physician faculty. Journal of Medical Education, 58(1), 45-50.

Davies, K. (2007). The information-seeking behaviour of doctors: a review of the evidence. Health Information and Libraries Journal, 24, 78-94.

Dawes, M. ve Sampson, U. (2003). Knowledge management in clinical practice: A systematic review of information seeking behavior in physicians. International Journal of Medical Informatics, 71(1), 9-15.

Demirkan, A. , Ekici, Y., Uçar, K. ve Başkan, S. (2000). Kanıta dayalı tıp. Ankara Üniversitesi Tıp Fakültesi Mecmuası, 53(4), 221-225.

Doğan, S. C. (2007). Tıp akademisyenlerinin elektronik veri tabanı ve elektronik dergi kullanımları: Hacettepe Üniversitesi örneği. Yayımlanmamış Yüksek Lisans Tezi, Hacettepe Üniversitesi, Ankara.

Dökmeci, İ. (2006). Tıp terimleri sözlüğü. İstanbul: Medikal Yayıncılık. 
Dökmeci, İ. (2007). Tıp terimleri cep sözlüğü. İstanbul: Medikal Yayıncılık.

Elayyan, R. M. (1988). The use of information by physicians. International Library Review, 20(2), $247-265$.

Eldredge, J. D. (2000). Evidence-based librarianship: An overview. Bulletin of the Medical Library Association, 88(4), 289-302. 20 Mart 2010 tarihinde http://www.ncbi.nlm.nih.gov/pmc/ articles/PMC35250/pdf/i0025-7338-088-04-0289.pdf adresinden erişildi.

Ergun, T. (2004). Kanıta dayalı tıp. TÜRKDERM, 38(1), 16-21.

Glasziou, P. ve Del Mar, C. (2007). Evidence-based practice: Bridging the gap between health care research and practice. Oxford: Blackwell Publishing.

Goodman, C. (1993). Literature searching and evidence interpretation for assessing health care practices. Stockholm: The Swedish Council on Technology Assessment in Health Care.

Green, M. L. ve Ruff, T. R. (2005). Why do residents fail to answer their clinical questions? A qualitative study of barriers to practicing evidence-based medicine. Academic Medicine, $80(2)$, 176-182.

Guyatt, G. H. (1991). Evidence-based medicine. ACP Journal Club, 114(özel sayı 2), A16.

Hacettepe Üniversitesi Tıp Fakültesi Hekimlik Uygulamaları.(2004). 10 Aralık 2010 tarihinde http:// www.medinfo.hacettepe.edu.tr/iyihekim.html adresinden erişildi.

Haug, J. D. (1997). Physicians' preferences for information sources: A meta-analytic study. Bulletin of the Medical Library Association, 85(3), 223-232.

Herner, S. (1958). The information-gathering habits of American medical scientists. Proceedings of the International Conference on Scientific Information içinde (s.277-285). Washington: National Research Council.

McAlister, F. A., Graham, I., Karr, G. W. ve Laupacis, A. (1999). Evidence based medicine and the practicing clinician. Journal of General Internal Medicine, 14(4), 236-242.

McKibbon, K. A. (1998). Evidence-based practice. Bulletin of the Medical Library Association, 86(3), 396-401. 20 Mart 2010 tarihinde http://www.ncbi.nlm.nih.gov/pmc/articles/PMC226388/pdf/ mlab00092-0108.pdf adresinden erişildi.

Miles, A., Polychronis, A. ve Grey, J. E. (2006). The evidence based health care debate 2006. Where we are now? Journal of Evaluation in Clinical Practice, 12(3), 239-247.

Montori, V. M., Tabini, C. C., ve Ebbert, J. O. (2002). A qualitative assessment of 1st-year internal medicine residents' perceptions of evidence-based clinical decision making. Teaching and Learning in Medicine, 14, 114-118.

Osiobe, S. A. (1985). Use of information resources by health professionals: A review of the literature. Social Science and Medicine, 21(9), 965-973.

Premsmit, P. (1990). Information needs of academic medical scientists at Chulalongkorn University. Bulletin of the Medical Library Association, 78(4), 383-387. 10 Mart 2010 tarihinde http://www. ncbi.nlm.nih.gov/pmc/articles/PMC225442/pdf/mlab00125-0065.pdf adresinden erişildi.

Rosenberg, W. M. ve Sackett, D. L. (1996). On the need for evidence-based medicine. Therapie, 51(3), 212-217. 
Sackett, D. L. ve Rosenberg, W. M. (1995). The need for evidence-based medicine. Journal of the Royal Society of Medicine, 88, 620-624.

Sackett, D. L., Rosenberg, W. M., Gray, J. A., Haynes, R. B. ve Richardson, W. S. (1996). Evidence based medicine: What it is and what it isn't. British Medical Journal, 312(7023), 71-72.

Sackett, D. L ve Richardson, W. L. (1997). Evidence Based Medicine. London: Curchill-Livingstone.

Sackett, D. L., Straus, S. E., Richardson, W.S., Rosenberg, W. ve Haynes, R.B. (2000). Evidence-based medicine: How to practice and teach EBM. Edinburgh: Churchill Livingstone.

Scherrer, C. ve Dorsch, J. L. (1999). The envolving role of the librarian in evidence-based medicine. Bulletin of the Medical Library Association, 87(3), 322-328.

Sincan, M. (2003). Kanıta dayalı tıp ve tıp kütüphaneciliği. Bilgi Dünyası, 4(1), 64-72.

Strasser, T. (1978). The information needs of practicing physicians in Northeastern New York State. Bulletin of the Medical Library Association, 62(2), 200-209.

Straus, S. E, Richardson, W. S., Glasziou, P. ve Haynes, R. B. (2005). Evidence-based medicine: How to practice and teach EBM. Edinburgh: Churchill Livingstone.

Sümbüloğlu, K. ve Akdağ, B. (2010). Kanıta dayalı tıp. Ankara: Sistem.

Thompson, M. L. (1997). Characteristics of information resources preferred by primarycare physicians. Bulletin of the Medical Library Association, 85(2),187-192.

Van Der Weyden, M. B (1999). Databases and evidence based medicine in general practice. The Medical Journal of Australia, 170(2), 52-53.

Wallace, R. L. (2007). ETSU medical residents' clinical information behaviours, skills, training and resourse use. Yayımlanmamış Doktora Tezi, East Tennessee Üniversitesi, Johnson.

Zawawi, S. ve Majid, S. (2001). The Information needs an seeking behaviour of the IMR biomedical scientists. Malaysian Journal of Library and Information Science, 5(1), 25-41. 